\title{
航海シミュレーションのための海上風 及び波浪の数值計算
}

曽田 泰介*・塩谷 茂明**・大澤 輝夫***牧野 秀成 ${ }^{* * *}$

\section{Numerical Calculation of Wave and Wind for Simulating Navigation}

\section{Taisuke SODA, Shigeaki SHIOTANI, Teruo OSAWA and Hidenari MAKINO}

\begin{abstract}
For safety coastal navigation, detailed information of wind and wave is very important and needed. In particular wind and wave would be changing dramatically in heavy situation such as a typhoon. In former part of this paper, the computational simulation of Japanese coastal area was explained. The wind of sea was calculated by numerical model of WRF and the ocean wave was calculated by numerical model of SWAN. In latter part of it, the numerical simulation of navigation in Japanese pacific coastal area was carried out.
\end{abstract}

The effects of wind and wave to navigation by container ship were examined numerically by the simulation. Keywords : Numerical navigation, SWAN model, WRF model, MMG, RIOS, Weather Routing キーワード: 数值ナビダーション、SWAN モデル、WRF モデル、MMG、RIOS、ウェザールーディング

\section{1.はじめに}

沿岸域においては地形等の影響により外洋に比べ、 より複雑な気象・海象現象が生じると考えられる。 このため、沿岸域においてより安全・安心な航行を 目指す上で空間的・時間的解像度の高い気象・海象 データが必要になることが考えられる。本研究では 波浪推算にSWANを用いて行うことで、詳細な海象 場の再現を目指した。

波高を推算する上で重要になるのは波浪の発達の 主な要因である海上風に関するデータである。現在、 米国環境予測センター（NCEP）やヨーロッパ中期 予報センター（ECMWF）等から予報または解析さ れた気象データを人手することができるが、波浪推 算のための空間的・時間的な解像度が十分であると はいえない。そのため、メソ気象モデル WRF を用 いてより十分な解像度を持った気象データを作成し
た。WRF とは米国環境予測センター（NCEP）や米 国大気研究センター（NCAR）などにより開発され た完全圧縮性・非静力学モデルである。WRFにより 推算された海上風を波浪推算モデル SWAN と組み 合わせることにより、正確な波浪推算を行うことを 目指した。SWAN とはオランダのデルフト工科大学 で開発された第三世代波浪推算モデルであり、浅海 域の波浪推算に特徽がある。

本研究では 2004 年 9 月に日本に接近・上陸した台 風 18 号時の風・波の数值シミュレーションを行った。 また、それらにより再現された気象・海象場におけ る航海シミュレーションに MMG モデルを用いて行 うことで、沿岸域での航行船舶への風及び波の影響 を検討した。MMG モデルとは日本造船学会試験水 槽委員会第 2 部会によって開発された、操縦性能の 数学モデル検討グループであり、船の操綐運動を運

\footnotetext{
* 学生会員 神户大学大学院海事科学研究科海事科学専攻（广658-0022 神戸市東灘区哚江南町 5-1-1）

** 正会員神戸大学自然科学系先端融合研究環

**** 正会員神戸大学大学院海事科学研究科 
動方程式に基づいて流体力学的に計算するための数 学モデルである。

著者らはこれまで大阪湾を対象に風及び波浪の影 響による航海シミュレーションを実施した ${ }^{1223344}$ 。今 回は大阪湾のような閉鎖海域でなく、今後内航船を 対象とする太平洋沿岸域に拡大して航海シミュレー ションを行った。

気象モデルWRF と波浪推算モデル SWAN を組み 合わせることで精度のよい気象海象場が再現でき、 航海シミュレーションに適用することで風・波の影 響が航行に有意に働くことがわかったので、ここに 報告する。

\section{2. 海上風・波浪の数值シミュレーション}

\section{1 計算対象期間}

計算対象期間は 2004 年 9 月 3 日 9 時から 2004 年 9 月 15 日 9 時の 12 日間である。Fig.1 に計算対象期 間中の気象庁発表の地上天気図を示寸。対象期間中 に台風 18 号が日本に接近した。台風 18 号は強力な 台風であり名護市では最低海面気圧 $924.4 \mathrm{hPa}$ を記 録しており、激甚災害に指定されている。台風 18 号は九州・中国地方を通過し、日本海側へ抜けた後、 温帯低気圧へと変化した。

\section{2 海上風の数值シミュレーション}

本研究において海上風の数值シミュレーションは WRF を用いて行った ${ }^{55)}$ 。WRF とは1.で記述のとお りの機関で開発され、実用的な気象予報や大気に関 する研究に使用できるよう開発された次世代メソ気 象モデルである。WRF は NCAR の管理する WRF-ARW モデルと NCEP の管理する WRF-NMM モデルがあるが、以降、WRF は WRF-ARW モデル を指すものとする。

WRFは完全圧縮性・非静力学モデルである。WRF は雲物理モデル，放射モデル，乱流モデル、地表面 モデルを組み合わせたものであり、最新の物理モデ ル、データ同化システム、ネスティングが装備され ており、計算スキームとしては3次精度のルング・ク ッタスキームや 5 次精度の風上差分など高精度な計 算スキームを採用しており、局地的な気象に対して 精度の高い計算が期待できる。

WRF の基礎方程式は運動方程式・連続の式・熱力 学の式・混合比の保存式からなる。

WRF により気象の再現をするにあたって初期条 件と境界条件が必要になる。本研究では米国環境予 測センター(NCEP)より GFS-FNL データを用いた。 GFS（Global Forecast System）とは米国環境予測セン ターにより開発された全球気象予報モデルであり、
GFS-FNL データは 6 時間間隔、 $1000 \mathrm{hpa}$ から $10 \mathrm{hpa}$ までの鉛直 25 層、緯度経度ともに一度間隔のデータ であり、気温・地表温度・湿度・海面温度 ・地表気 圧・地表風・風シアーなど 25 の変数が含まれている。
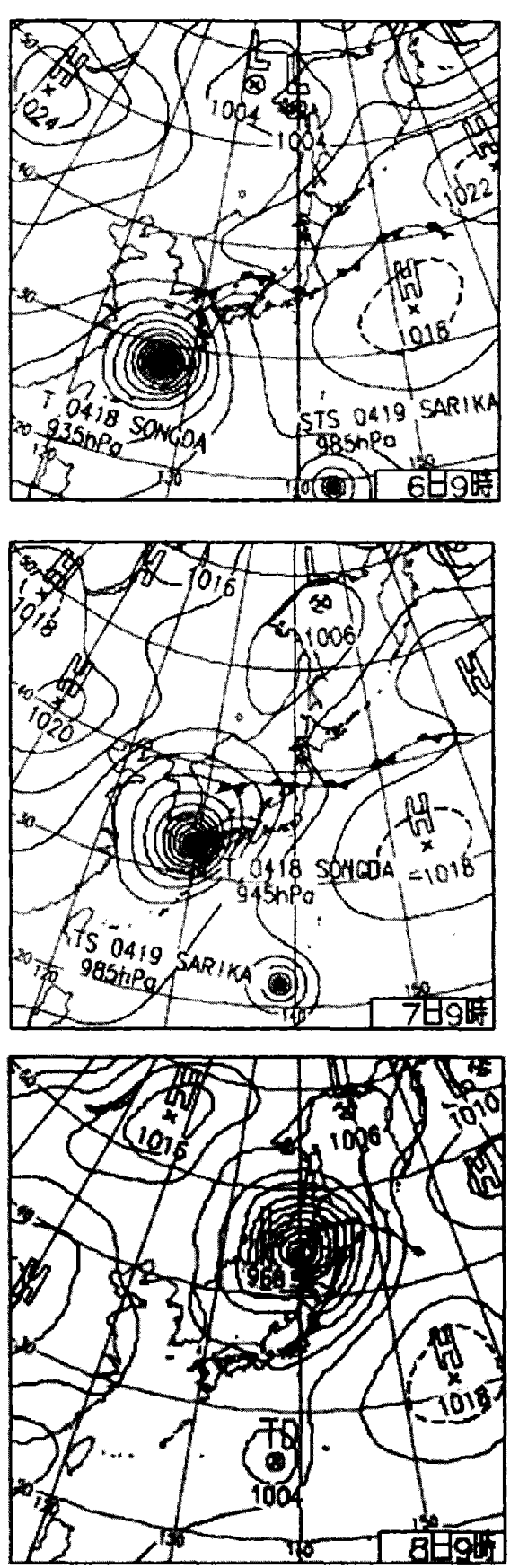

Fig.1 Atmospheric chart of numerical simulation

本研究において WRF を実行するにあたり、より 精度の高い計算を目指すため、Fig.2 に示す大領域 (d01) と小領域 $(\mathrm{d} 02)$ の 2 層の領域に分けた。地形デー 夕は $\mathrm{d} 01$ においては 10 分間隔、d02 においては 30 秒間隔のデータを用いネスティングにより計算を行 った。d01、d02 における各種計算条件を Table.1に 示す。 
Table.1 Condition of calculation by WRF

\begin{tabular}{|c|c|c|}
\hline & $\mathrm{d} 01$ & $\mathrm{~d} 02$ \\
\hline Dimension & $176 \times 149 \times 20$ & $235 \times 135 \times 20$ \\
\hline Mesh size & $10(\mathrm{~km})$ & $2(\mathrm{~km})$ \\
\hline Time step & $60(\mathrm{~s})$ & $12(\mathrm{~s})$ \\
\hline Start Time & \multicolumn{2}{|c|}{$2004-09-03-09: 00: 00$} \\
\hline End Time & \multicolumn{2}{|c|}{$2004-09-15-09: 00: 00$} \\
\hline
\end{tabular}

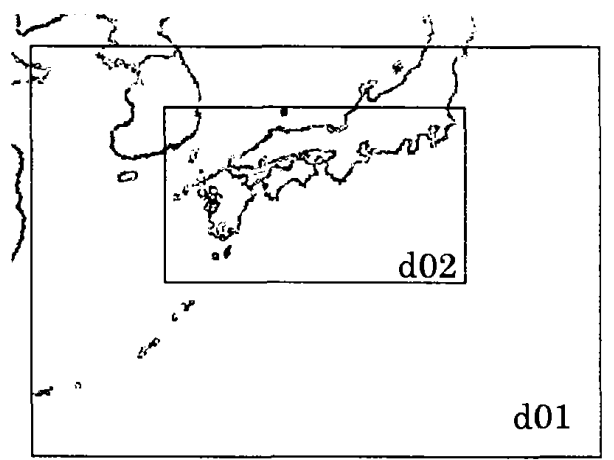

Fig.2 Two calculated areas

神津島、神戸、高知における WRF により求めら れた風速・風向と気象庁観測点の観測值との比較を Fig.3に示す。横軸は時間、縦軸は風速を示す。破線 は観測結果、太い実線は数值計算結果を示す。なお、 観測値については、観測地の高度で観測された風速 に対数則を用い地上 $10 \mathrm{~m}$ の推測值とした。

神戸においては定性的にはよくあっているが台風 接近時付近の風速を過大に評価している。神戸の風 速は他の観測点と比べ短時間の間に発達し、減衰し ていることがわかる。本研究では初期・境界条件と して経度緯度方向に 1 度間隔、 6 時間間隔のデータ を用いており、短期間に大きく変動する台風の気象 場を表現するには時間的・空間的に粗すぎ、さらに、 神戸は他の海域と異なって湾内で閉鎖海域であるた め、周辺の陸地の影響を受け、計算と観測値に差が 生じたものと思われる。このような要因が重なり、 神戸での風速の過大評価につながっている可能性が ある。

神津島・高知では風速・風向のいずれも両者はよ く一致している。風向に関しては風向 $0^{\circ}$ と $360^{\circ}$ を図 の上下辺に分離して表示しているので、一致しない ように見える。全般に、台風の接近時に両者はよく 一致しているが、それ以外の時間では観測した風向 は大きく変動しているので、両者に多少の差がみら れる。

各観測点での風速の観測值と推算値の誤差の平均 2 乗偏差は、神津島で $3.5 \mathrm{~m} / \mathrm{s}$ 、神戸で $3.0 \mathrm{~m} / \mathrm{s}$ 、高知
で $2.3 \mathrm{~m} / \mathrm{s}$ 、相関係数は、神津島で 0.79、神戸で 0.76 、 高知で 0.89 であった。これら三地点の結果から、本 数値計算で概ね正確な風の分布が再現できているも のと考えられる。
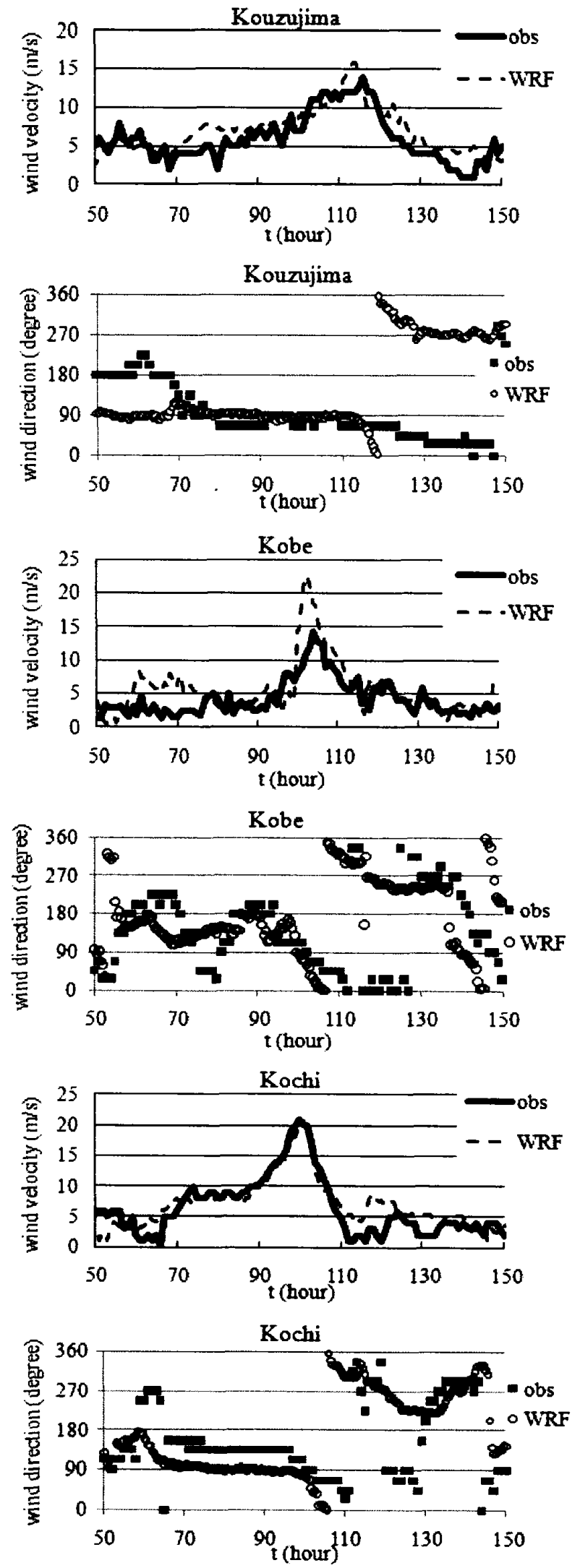

Fig.3 Comparison of calculated and observed wind velocity and direction 


\section{3 波浪の数值シミュレーション}

本研究では波浪の数値シミュレーションに SWAN を用いた。SWAN では哚海域においてはWAM モデ ルを用い、浅海域における浅水砕波によるエネルギ 一散逸、極浅海域で顕著となる 3 波共鳴非線形相互 作用による成分波間でのエネルギー輸送など、浅水 域での波浪伝搬が考慮されている。

SWANではエネルギースペクトルを相対角周波数 で割った作用量平衡方程式を解くことで流れの向き を考慮した波浪推算が可能である。作用量平衡方程 式は次式で表わされる。

・平面座標の場合

$\frac{\partial N}{\partial t}+\frac{\partial}{\partial x}\left(C_{x} N\right)+\frac{\partial}{\partial y}\left(C_{y} N\right)+\frac{\partial}{\partial \sigma}\left(C_{\sigma} N\right)+\frac{\partial}{\partial \theta}\left(C_{\theta} N\right)$

$=\frac{S}{\sigma}$

・球面座標系の場合

$\frac{\partial N}{\partial t}+\frac{1}{\cos \phi} \frac{\partial}{\partial \phi}\left(C_{\phi} \cos \phi N\right)+\frac{\partial}{\partial \lambda}\left(C_{\lambda} N\right)+\frac{\partial}{\partial \sigma}\left(C_{\sigma} N\right)+$

$\frac{\partial}{\partial \theta}\left(C_{\theta} N\right)=\frac{S}{\sigma}$

ここに(1)式の左辺第 1 項は局所的な時間変化、第 2 項および第 3 項はそれぞれが $\mathrm{x}$ 及び $\mathrm{y}$ 方向の空間変 化(移流項)を表し、 $C_{x}$ および $C_{y}$ は伝播速度である。

第 4 項は特性速度 $C_{\sigma}$ による相対角周波数に対する変 化、第 5 項法特性速度 $C_{\theta}$ による伝播方向一の変化を 表す。(2)式の $\varphi$ 、入および $\theta$ はそれぞれ緯度、経度 及び波向である。

本研究では沿岸域での波浪の精度検証を行うため、 波の屈折・回折についても考慮する。

また、右辺のエネルギーの出入りを表すエネルギ ーソース項 $S$ は以下のように表せる。

$S=S_{i n}+S_{d s}+S_{b f}+S_{b r}+S_{n l 4}+S_{n l 3}$

ここに、 $\mathrm{S}_{\mathrm{in}}$ は風から波へのエネルギ一輸送項、 $S_{\text {in }}$ は 白波によるエネルギ一散逸項、 $S_{b f}$ は底面摩擦による エネルギー散冕項、 $S_{b r}$ は砕波によるエネルギー散逸 項、 $S_{n l 4}$ は 4 波共鳴による非線形相互作用、 $S_{n l 3}$ は 3 波共鳴による非線形相互作用を表す。

本研究ではSWANによる波浪推算において、波浪 の発達は海流等の流れの影響は考虑しておらず、す べて風によるものとした。波浪推算の計算フローチ ヤートを Fig.4 に示す。

SWANにより推算された有義波高をナウファスに よる観測值と比較した。ナウファス（全国港湾海洋 波浪情報網： NOWPHAS : Nationwide Ocean Wave information network for Ports and HArbourS )とは、国 土交通省港湾局、各地方整備局、北海道開発局、沖 䋥総合事務局、国土技術政策総合研究所および独立 行政法人港湾空港技術研究所の相互協力のもとに構 築・運営されている我が国沿岸の波浪情報網である。 港湾空港技術研究所は、1970 年以降継続して、ナウ ファス波浪観測データの集中処理・解析を担務して おり、2009 年 11 月現在において、69 観測地点（波 高・周期 69 地点、波向 58 地点）で観測された全国 沿岸の波浪情報は、リアルタイムで港湾空港技術研 究所に収集されている。

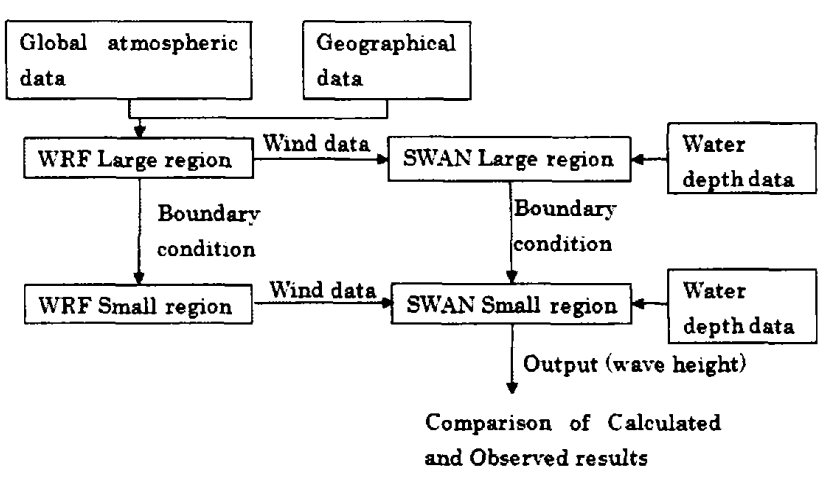

Fig.4 Flow chart for calculation of wave by SWAN

SWAN による計算において、より精度の向上を目 指すためにネスティングを用いた。計算領域は Fig2 のWRF で示した大領域(d01) と小領域(d02)と同じも のである。格子間隔は $\mathrm{d} 01$ で $2 \mathrm{~km} 、 \mathrm{~d} 02$ で $1 \mathrm{~km}$ とし た。 d01、 $\mathrm{d} 02$ ともに方向分割数は 36、計算対象周波 数は $0.04 \mathrm{~Hz} \sim 1.0 \mathrm{~Hz}$ までとし、周波数分割数は 30 と した。計算時間間隔は $\mathrm{d} 01$ で 15 分、 $\mathrm{d} 02$ で 10 分と し、30 分毎の有義波高を出力した。

Table.2 にそれぞれの計算領域における計算条件 を示す。

Table. 2 Condition of calculation by SWAN

\begin{tabular}{|c|c|c|}
\hline & $\mathrm{d} 01$ & $\mathrm{~d} 02$ \\
\hline Dimension & $352 \times 298$ & $470 \times 270$ \\
\hline Mesh size & $2(\mathrm{~km})$ & $1(\mathrm{~km})$ \\
\hline Time step & $15(\mathrm{~m})$ & $10(\mathrm{~m})$ \\
\hline Start Time & $2004-09-03-09: 00: 00$ \\
\hline End Time & $2004-09-15-09: 00: 00$ \\
\hline $\begin{array}{c}\text { number of } \\
\text { frequencies }\end{array}$ & $30(0.04 \mathrm{~Hz}-1 \mathrm{~Hz})$ & $30(0.04 \mathrm{~Hz}-1 \mathrm{~Hz})$ \\
\hline $\begin{array}{c}\text { number of meshes } \\
\text { in } \theta\end{array}$ & 36 & 36 \\
\hline
\end{tabular}



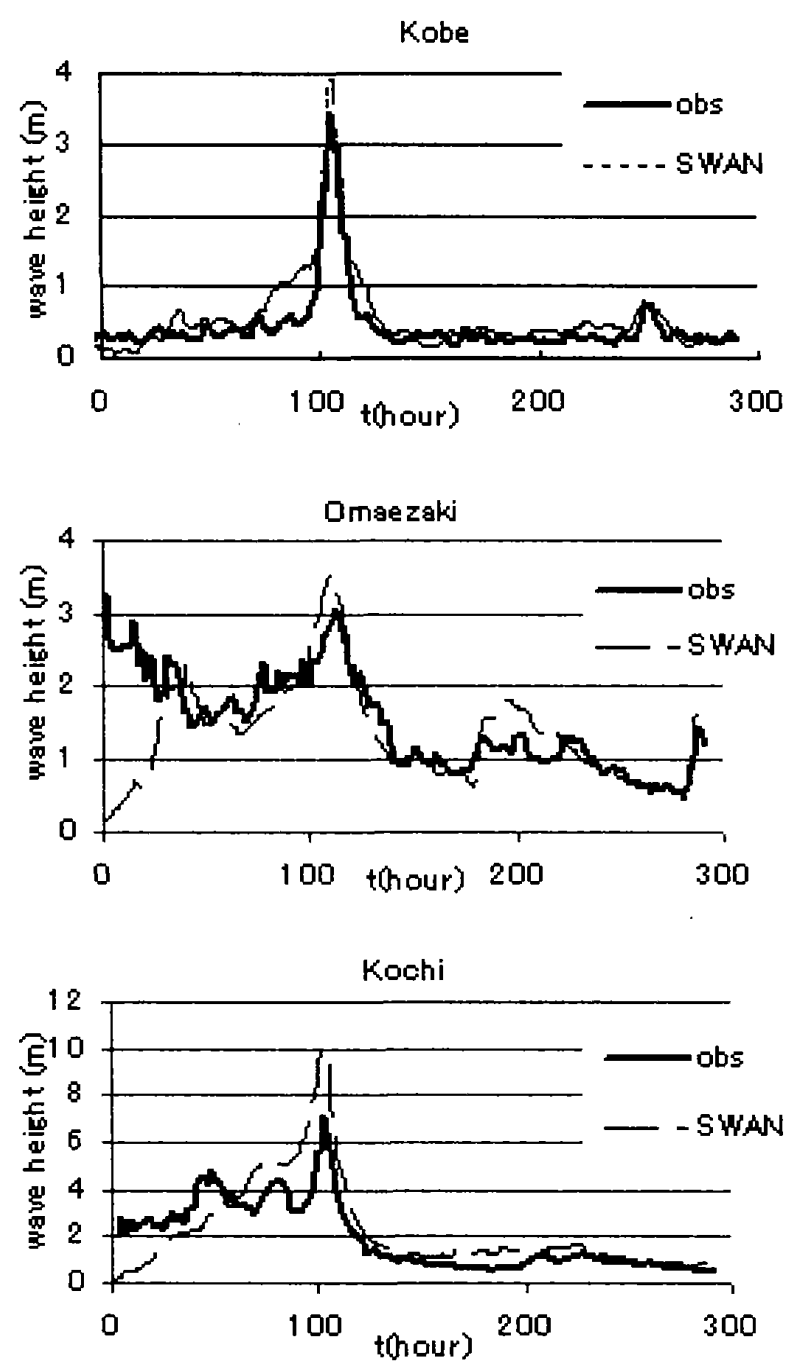

Shibusi

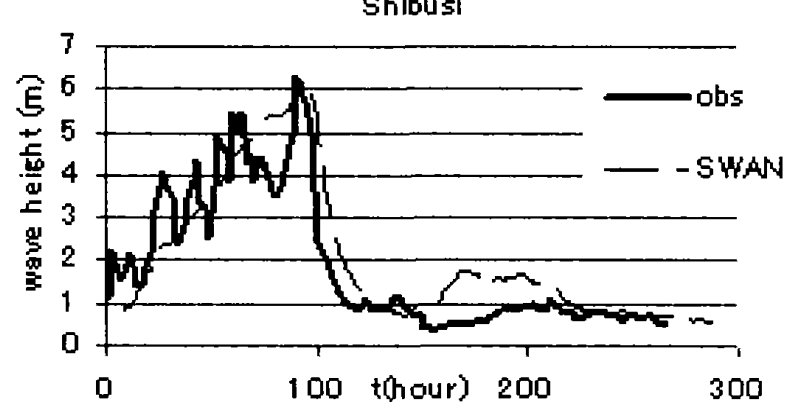

Fig.5 Comparison of calculated and observed significant wave height

Fig.5 に御前崎、神戸、高知、志布志の有義波高の 推算値と観測值の時系列の比較を示す。横軸は時間、 縦軸は有義波高を示す。

高知では台風襲来時の波高のピークが過大に推算 されているようである。本研究において最大の波浪 の計算領域は d01 であり、 d01 より外側の気象・海 象の影響については考慮されていない。Fig.3より高 知における推算された風速について過大であるとは 言えないことから、計算領域外の南方からの波浪の
影響があることが考えられる。

神戸については推算された風速について過大であ ったものの、神戸は内湾であり吹送距離が短く、風 向の変化も大きかったため、台風接近時の波浪のピ 一ク值に大きな差は見られなかったと考えられる。

いずれの地点においても観測值と推算値はよく一 致し、概ね精度のよい波高の推算ができていると考 えられる。

\section{3. 航海シミュレーション}

航海シミュレーションは、操縦運動数学モデル MMG を適用した ${ }^{738)}$ 。沿岸航海の場合は、地形等の 影響により時間的・空間的に細かな気象・海象デー タが必要になると考えられるため、30 分毎に気象・ 海象のデータを更新し、航海シミュレーションを行 った。

航海シミュレーションは、海上風の影響のみ、波 浪の影響のみ、海上風と波浪の影響を考慮する場合、 海上風と波浪の影響を受けない場合の4 ケースに分 け、それぞれの航跡を比較した。

Fig.6に本研究で用いた MMG の空間固定座標と船 体固定座標の関係を示す。

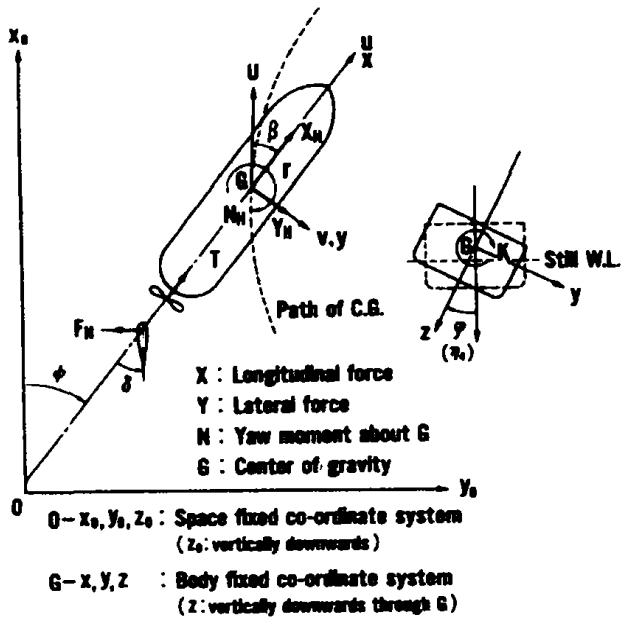

Fig.6 Coordinate system of ship maneuvering simulation

空間固定座標系を船体固定座標系に変換後の船体 運動方程式は次式であらわされる

$$
\begin{aligned}
& \left(m+m_{x}\right) \dot{u}-\left(m+m_{y}\right) v r=X \\
& \left(m+m_{y}\right) \dot{v}+\left(m+m_{x}\right) u r=Y \\
& \left(I_{z z}+J_{z z}\right) \dot{r}=N
\end{aligned}
$$

ここに $m$ は船体の質量、 $m_{x}$ は $\mathrm{x}$ 軸方向の付加質量、 $m_{y}$ は $\mathrm{y}$ 軸方向の付加質量、 $I_{z z}$ は $\mathrm{z}$ 軸回りの慣性モ一 メント、 $J_{z z}$ は $\mathrm{z}$ 軸回りの付加慣性モーメント、u、v、 $r$ はそれぞれ船速の $\mathrm{x}$ 方向成分 $\cdot \mathrm{y}$ 方向成分 - 回頭 
角速度、 $X 、 Y 、 N$ は $\mathrm{x}$ 軸、 $\mathrm{y}$ 軸方向の力、重心回り の回頭モーメントである。

本研究の MMG では船全体に働く流体力を、船体、 プロペラ、舵、風、波などのそれぞれ単体に働く成 分に分離して次式で表す。

$$
\begin{aligned}
& X=X_{H}+X_{P}+X_{R}+X_{A}+X_{W} \\
& Y=Y_{H}+Y_{P}+Y_{R}+Y_{A}+Y_{W} \\
& N=N_{H}+N_{P}+N_{R}+N_{A}+N_{W}
\end{aligned}
$$

添え字の $H 、 P 、 R 、 A 、 W$ はそれぞれ船体(Hull)、プ ロペラ(Propeller)、舵(Rudder)、風(Air)、波(Wave)を 示している。

風による力 $X_{A} 、 Y_{A} 、 N_{A}$ は次のように表わされる。

$$
\begin{aligned}
& X_{A}=\frac{\rho_{A}}{2} V_{A}^{2} A_{T} C_{X A}\left(\theta_{A}\right) \\
& Y_{A}=\frac{\rho_{A}}{2} V_{A}^{2} A_{L} C_{Y A}\left(\theta_{A}\right) \\
& N_{A}=\frac{\rho_{A}}{2} V_{A}^{2} L A_{L} C_{N A}\left(\theta_{A}\right)
\end{aligned}
$$

ここに $\rho_{A}$ は空気の密度、 $\theta$ は相対風向、 $V_{A}$ は相対風 速、 $A_{T}$ は船体水線上正面投影面積、 $A_{L}$ は船体水線 上側面投影面積、 $C_{X A} 、 C_{Y A} 、 C_{N A}$ は風圧力倸数であ る。本研究では対象船舶の風圧力係数の推定に藤原 の式を用いた 9)。

波浪による力 $X_{W} 、 Y_{W} 、 N_{W}$ は次式のように表わさ れる。

$$
\begin{aligned}
& X_{W}=\rho g h^{2} B^{2} / L \overline{C_{X W}}\left(U_{0}, T_{V}, \chi-\psi_{0}\right) \\
& Y_{W}=\rho g h^{2} B^{2} / L \overline{C_{Y W}}\left(\omega_{0}, \chi-\psi_{0}\right) \\
& N_{W}=\rho g h^{2} B^{2} / L \overline{C_{N W}}\left(\omega_{0}, \chi-\psi_{0}\right)
\end{aligned}
$$

ここに $\rho$ は海水の密度、 $g$ は重力加速度、 $h$ は入射波 の振幅、 $\overline{C_{X W}} 、 \overline{C_{Y W}} 、 \overline{C_{N W}}$ は規則波中における波 漂流係数を用いた短期予測の平均值、 $T_{v}$ は平均波周 期、 $\chi-\psi_{o}$ は相対的な波向きである。

波浪中の船体にかかる定常力 $X_{W} 、 Y_{W}, N_{W}$ の推計 は RIOS による短期応答を用いて行った ${ }^{10}$ 。 RIOS とは実海域船舶性能研究イニシアティブ（The Research Initiative on Oceangoing Ships)の略称であり、 大阪大学大学院工学研究科地球総合工学専攻船舶海 洋工学コースに設置された実海域での船舶性能の向 上と、船舶性能の評価手法に関する研究開発拠点で ある。

MMG を用いた航海シミュレーションを行った対 象船舶は SR108 であり、主要目を Table.3に、線図 を Fig.7 に示す。 $L_{P P}$ は垂線間長、 $L_{W L}$ は水線長、B は幅、 $d$ は喫水、 $x_{G}$ は浮心位置座標、 $C_{b}$ は方形倸数、
$\Delta$ は排水量、 $S$ は浸水面積、 $D_{p}$ はプロペラ直径、 $p$ はプロペラピッチ比、 $H_{R}$ は舵スパン長、 $B_{R}$ は舵コー ド長、 $A_{R}$ は舵面積を表す。

Table.3 Principal properties of SR 108

\begin{tabular}{|c|c|}
\hline Symbol & ship \\
\hline$L_{P P}(m)$ & 175.00 \\
\hline$L_{W L}(m)$ & 178.21 \\
\hline$B(m)$ & 25.40 \\
\hline$d(m)$ & 9.50 \\
\hline$x_{G}(m)$ & -2.545 \\
\hline$C b$ & 0.572 \\
\hline$\Delta($ ton $)$ & 24,801 \\
\hline$S(m)$ & 5,499 \\
\hline$D p(m)$ & 6.507 \\
\hline$p$ & 0.7348 \\
\hline$H_{R}(m)$ & 7.70 \\
\hline$B_{R}(m)$ & 4.215 \\
\hline$A_{R}\left(m^{3}\right)$ & 32.46 \\
\hline
\end{tabular}

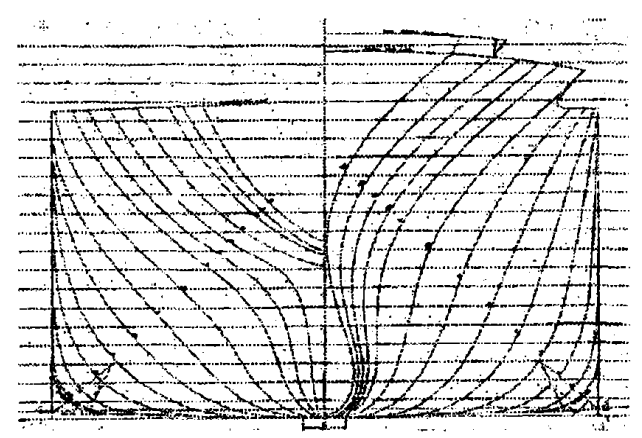

Fig.7 Body lines of SR 108

本船はコンテナ船であり、平水中での速力を 24.3 $\mathrm{kt}(\mathrm{Fn}=0.3)$ とした。計画航路は Fig.8 に示す神津島か ら鹿児島西沖までを直線で結んだものとし、その東 航、西航の航海シミュレーションを行った。また、 Fig.8の図中に風及び波浪の数值計算及び観測結果 の比較を行った位置を記した。いずれも出発時刻は Fig.1の中央の図に示す通り、台風が九州西岸に接近 した 9 月 7 日午前 0 時とし、航海時間 18 時間の航海 シミュレーションを行った。

なお、オートパイロットとして次式に示す一次遅 れの制御を行った。

$$
\delta^{*}=\delta+T_{e} \frac{d \delta}{d t}
$$

$\delta^{*}$ は指令舵角、 $\delta$ は舵角、 $T_{E}$ は操舵機の時定数を表 す。 
指令舵角 $\delta^{*}$ 注次式に表される。

$$
\delta^{*}=C_{1} \psi-C_{2} r
$$

$\psi$ は指令針路と実針路の針路偏差、rは旋回角速度 である。本研究において、 $T_{E}$ は $2.5 、 C_{1}$ は $1.5 、 C_{2}$ は 8.0 と設定した。

Fig.9に航海シミュレーション開始 11 時間後の有 義波高及び風向の分布を示す。波高は色の濃淡で表 わし、黑い部分が高波高域である。矢印は風向を表 す。Fig.10に同時刻の波向の分布を示す。図中の色 の濃淡は Fig.9 と同様に波高分布を示し、矢印が波 向である。台風域内に高波高域があり、また台風周 辺の海上風は反時計回りの流れが、また航路上には 南の強風が連吹していて、波浪および風が十分シミ ユレーションされている。同時に風の分布に従って 波高も同様の分布を示している。

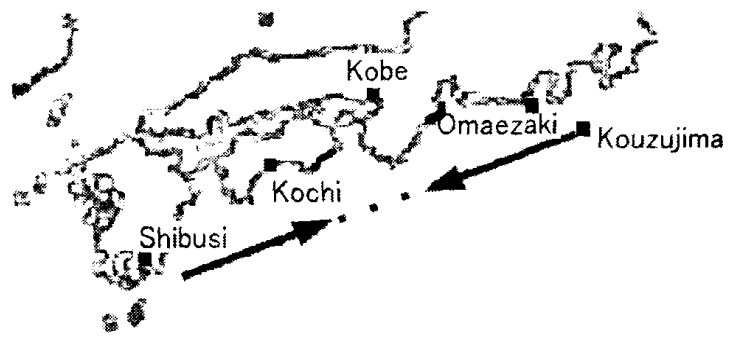

Fig. 8 Course line of navigational simulation

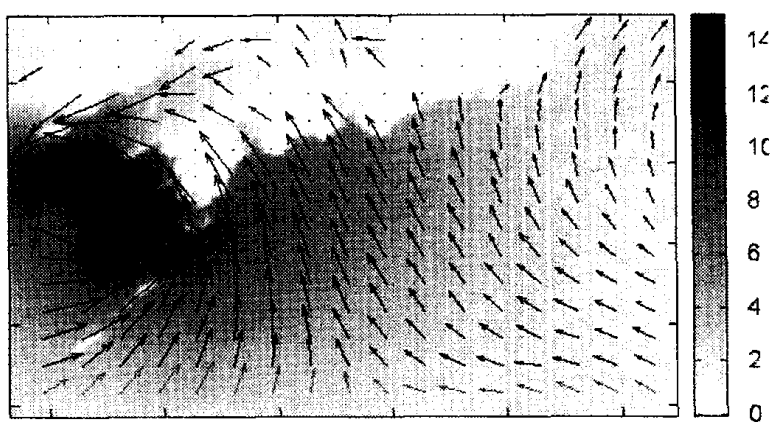

Fig.9 Distribution of calculated wind

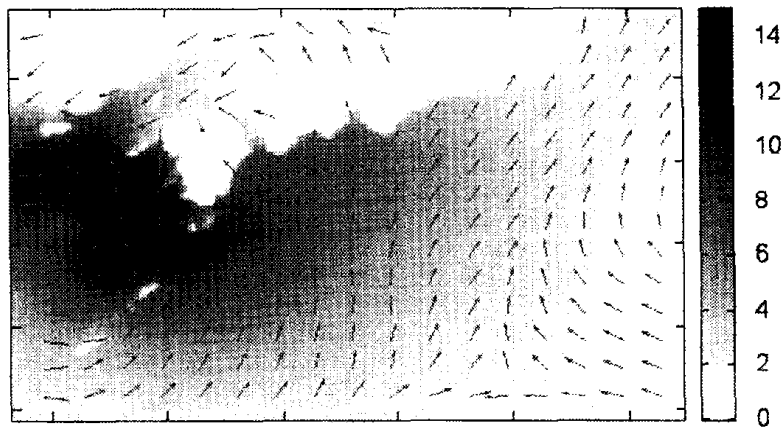

Fig. 10 Distribution of calculated wave
航海シミュレーションにおいて東向きの航路にお ける船位を Fig.11、西向きの航路における船位を Fig.12 にを示す。

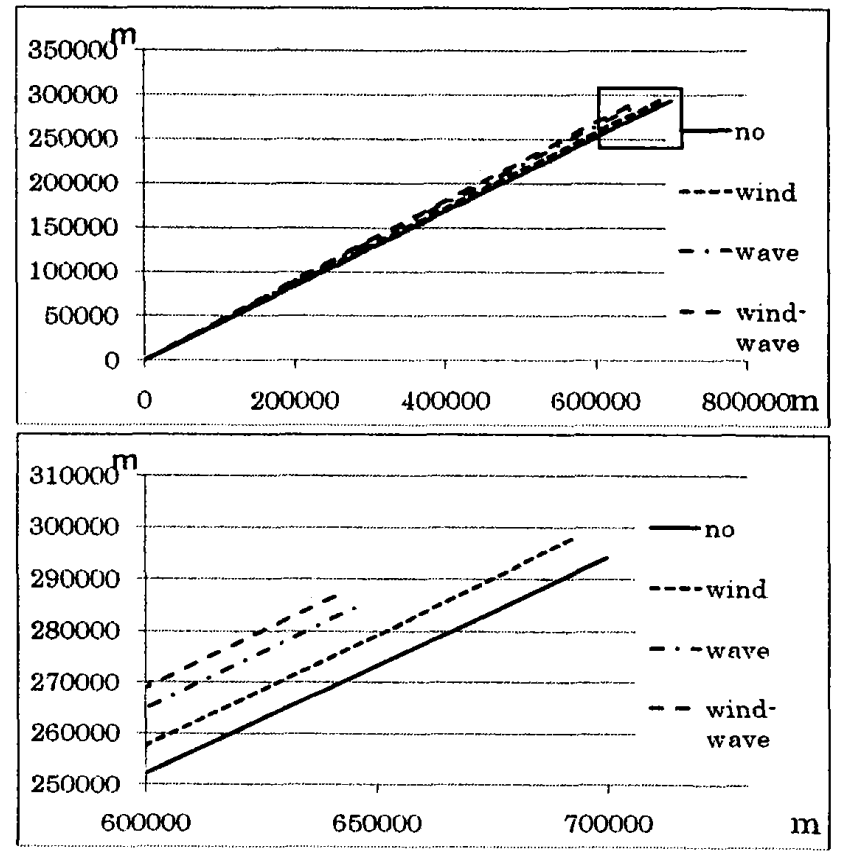

Fig.11 Comparison of wind and wave effect (East course)
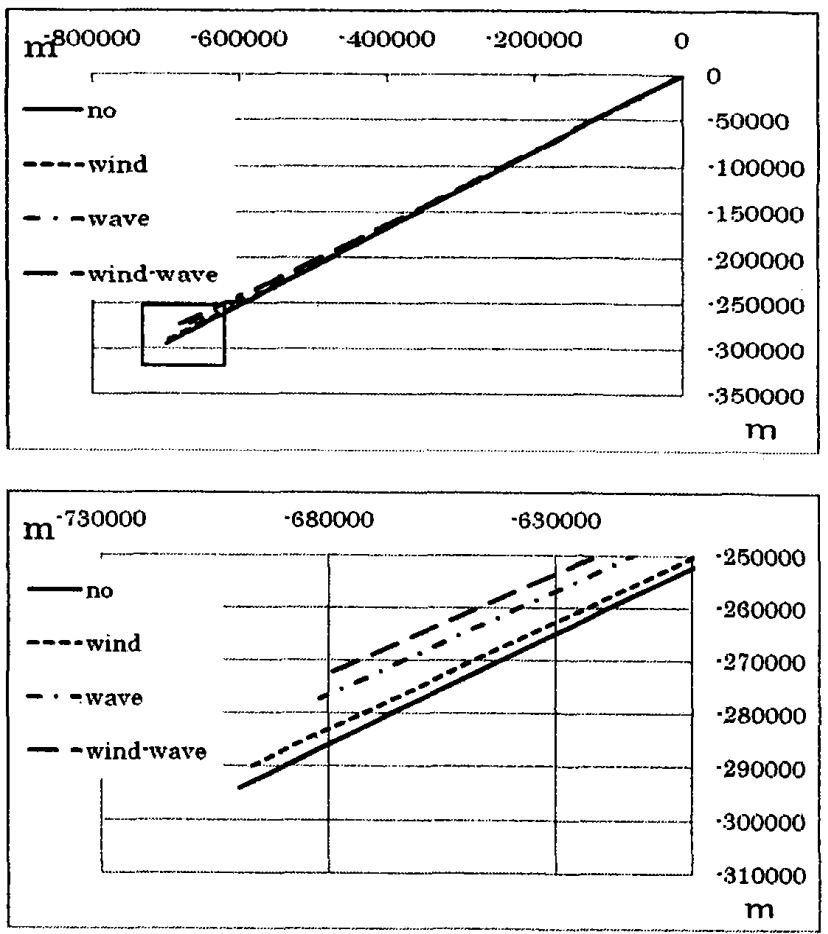

Fig.12 Comparison of wind and wave effect (West course)

出発地点を原点とした x-y 座標を取り、航跡をメ 一トルで表した。上図は全航跡を、下図は風及び波 浪の影響の比較が容易にできるように上図の四角枠 
内の拡大した航跡を示す。横軸及び縦軸は船舶の横 流れ量が長さ単位で比較可能なように距離(m)で表 示した。図中、実線(no)は風及び波浪の影響のない 場合、点線(wind)は風のみ、一点鎖線(wave)は波浪の み、破線(wind-wave)は風及び波浪の両方の影響によ る航跡を示す。

本航路では、航海中に相対方位で船体の横方向に 風及び波浪が影響しているので、風下側に横流れが 生じている。風及び波浪の影響を比較すると風より も波浪のほうが船舶に与える影響が大きい。従って 航海距離に関して、風と波浪の両者の影響による航 程は風よりも波浪の影響のほうが顕著であるため、 波浪のみの影響と同程度の航海距離となっている。

東航が西航と比心゙、後方からの波向きであるにも かかわらず、東航の航行距離が西航に比心゙短いのは、 東航は航海の初期段階において、台風による高波高 域を通過しており、西航に比べて波高の高い海域を より長く航行しているためと考えられる。

航路を東航及び西航するいずれの場合においても、 風及び波の影響が十分にシミュレーションできてい る。

\section{4. まとめ}

航行船舶への気象・海象の影響について航海シミ ユレーションを用いて調查した。航海シミュレーシ ヨンは日本の太平洋側沿岸で行った。航海シミュレ ーションは風のみ、波浪のみ、および風と波浪の組 み合わせの影響について調査した結果、以下の通り の主要な結論を得た。

（1）台風襲来時の荒天時においてメソ気象モデル WRF を用いた正確な海上風の数值シミュレー ションが可能となった。

（2）WRF で数値計算された海上風を用いた波浪の 数值シミュレーションが可能となった。第 3 世 代波浪推算モデル SWANを用いた正確な波浪の 推算が可能となった。

(3) 再現した気象・海象場に MMGによる航海シミ ユレーションを組み合わせることで、風・波を 考慮した船位の推定が可能となった。

(4) 本シミュレーション結果では、航行船舶に対し て風よりも波浪の影響のほうが顕著である。

(5) 本研究で太平洋沿岸のような沿岸域での航海シ ミュレーションを実施することが可能となった ので、内航船舶の航海に適用することが可能と なった。

本研究の今後の発展として海流の数值シミュレー
ションも加え、実船実験による風、波浪及び海流の 影響について調査し、本航海シミュレーションとの 定量的比較を予定している。

本研究は平成 20 年に文部科学省で採択された運 営費交付金特別教育研究推進「輸送の三原則を考慮 した国際海上輸送システム創出の研究」の一環とし て実施されたことを付記する。

\section{参考文献}

(1) 夏海波, 塩谷茂明, 万田敦昌, 小林英一, 若林 伸和：潮流シミュレーションを用いた航海への 潮流の影響の調查について, 日本航海学会論文 集，第 116 号, pp.61-67, 2007

（2）夏海波, 塩谷茂明, 大澤輝夫, 小林英一: 海上 風の数値予測と風圧影響下の航海シミュレー ション, 日本航海学会論文集, 第 117 号, pp.151-158, 2007

（3）塩谷茂明，小林英一, 大澤輝夫, 牧野秀成：波 浪の数值シミュレーションを考慮した数值ナ ビゲーションについて，日本航海学会論文集， 第 122 号，pp.243-251，2010

（4）塩谷茂明，陳瀚，大澤輝夫，小林英一：海上 風と潮流の数值予測を考慮した航海シミュレ 一ション，日本航海学会論文集，第 123 号, pp.53-60, 2010

（5）間瀬肇，勝井伸悟，安田誠宏，Tracey H. Tom, 小川和幸: GFS-WRF-SWAN システムによる 3 シーズンの波浪予測とシステムの検証, 海洋 開発論文集第 22 巻，pp.109-114，2006

（6）新谷哲也: 気象モデルWRFを用いた湖上風の再 現と波浪推算, 水工学論文集, 第52巻, pp. $1237-1242 ， 2008$

（7）小瀬邦治, 湯室彰擬規, 吉村康男 : 操縦運動の 数学モデルの具体化, 第 3 回操綎性シンポジウ ム, pp.28-81, 1981

（8）小川陽弘：操縦運動の数学的モデルの基礎, 3 回操緃性シンポジウム, pp.9-26, 1981

（9）藤原敏文、上野道雄、二村正：船体に働く風圧 力の推定、日本造船学会論文集813号、pp77-90, 1998

(10) 実海域船舶性能研究イニシアティブ RIOS ホー ムページ、http://133.1.7.5/

\section{質疑応答}

石田廣史（神戸大学）：

（1）風速シミュレーション值と実測風速を比較す 
る際の基準高度はいくらですか。

（2）実測高度の不足を基淮高度の風速に修正する 際、風速プロファイルモデルは何を用いまし たか。

\section{曽田泰介（神戸大学）：}

御質問ありがとうございます。

（1）基準高度は地上 $10 \mathrm{~m}$ としました。

（2）基準高度への風速の修正は対数則を用いまし た。

河合雅司（富山高等専門学校）:

波浪推算結果で、神戸では推算值と観測值がよく 一致しているが、高知では少しずれていたとのこ とですが、その原因についてコメントさせていた だきます。神戸は瀬戸内海にあり、うねりの影響 は少ないですが、高知は外洋に面しておりうねり の影響を大きく受けます。うねりは海流の影響を 受けてその波向きが偏向しますが、この海流によ るうねりの伝播方向の変化を考慮していないため に高知で推算值と計算值がずれているのではない かと思います。

\section{曽田泰介（神戸大学）：}

貴重なコメントありがとうございます。

本研究では海流の影響を考慮しておらず、御指摘 の通りう㸚り・海流間の作用は考慮すべき問題で あると考えます。また、海流の向きと風向の関倸 で波浪の発達状況は異なってくることからも外洋 に面した海域での波浪推算に海流の影響は重要で あると考えます。この点については、今後の発展 問題としてとらえ、海流の影響を考慮したいと考 えています。 